\title{
MENINGKATKAN HASIL BELAJAR SISWA PADA MATAPELAJARAN IPS DENGAN METODE MIND MAPPING
}

\author{
Maya Kartika Sari *
}

\begin{abstract}
Social science has been viewed as naturally theoretic, which requires students to memorize all learned materials. The learning experience will be stucked in freez learning atmosphere when the teacher traditionally preeches and dictates against the students, as the teacher-centered approaches have run. This model of teaching produces passive students with low acheivement. In effort of dveloping the vivid learning experience, variative models of teaching must be applied by the teacher. Through this research, the researcher proposes Mind Mapping Teaching Method, hopping that the the students learning activities and achievement can be developed. Mind mapping teaching method can tentatively encourage student to be active, innovative, creative and imaginative along the way with the learning process. The application of mind mapping teaching method can hopefully develop students learning activities and achievement through the given action research design.
\end{abstract}

Key words: Learning achievement, Mind Mapping Method, Social Science

\begin{abstract}
Abstrak
Ilmu Pengetahuan Sosial (IPS) merupakan mata pelajaran yang bersifat teoritis yang mengharuskan siswa memahami materi pelajaran yang dikaji. Pembelajaran IPS akan menimbulkan kejenuhan dan ketidaktertarikan apabila guru dalam menjelaskan materi hanya berceramah dan mencatat saja, serta pembelajaran hanya terfokus pada guru (teacher oriented). Hal ini menimbulkan hasil belajar siswa pada mata pelajaran IPS menjadi kurang maksimal dan cenderung siswa menjadi pasif dalam pembelajaran. Siswa diupayakan aktif dalam pembelajaran, karena itulah guru harus mampu mengoptimalkan potensi siswa. Guru harus berupaya meningkatkan kualitas pembelajaran mata pelajaran IPS, dengan memvariasi metode belajar. Selain itu guru harus mengupayakan pembelajaran yang menarik yakni: mengaktifkan siswa, memunculkan kreativitas, imaginasi siswa dalam mengkaji materi pelajaran, dan mengkondisikan pembelajaran yang kondusif. Metode pembelajaran yang mampu mengaktifkan potensi siswa salah satunya
\end{abstract}

* Maya Kartika Sari adalah Dosen Program Studi PGSD FIP IKIP PGRI Madiun 
adalah Metode Mind Mapping. Siswa dalam Mind Mapping akan mampu menggali kemampuan berpikir kritis dalam mengkonsepkan materi yang akan dibuat dalam map (peta), meningkatkan kemampuan dalam berinovasi belajar, meningkatkan kecerdasan visual, dan mengoptimalkan otak. Diharapkan dengan metode belajar Mind Mapping mampu meningkatkan hasil belajar siswa terutama pada mata pelajaran IPS.

Kata Kunci: Hasil Belajar, Mind Mapping, IPS

\section{A. PENDAHULUAN}

Pembelajaran Ilmu Pengetahuan Sosial (IPS) sebagai salah satu program pendidikan yang membina dan menyiapkan peserta didik sebagai warga negara yang baik dan memasyarakat diharapkan mampu mengantisipasi berbagai perubahan yang terjadi di masyarakat sehingga siswa mempunyai bekal pengetahuan dan keterampilan dalam melakoni kehidupan di masyarakat. Guru di tuntut untuk mampu mengikuti dan mengantisipasi berbagai perubahan masyarakat tersebut, sehingga program pembelajaran yang dilakukannya dapat membantu siswa dalam mempersiapkan dirinya sebagai warga masyarakat dan warga negara untuk memecahkan berbagai persoalan yang dihadapi dalam kehidupannya sehari-hari. Guru harus cermat dalam memilih model pembelajaran dan merancang program serta strategi pembelajaran, sehingga pembelajaran yang dilakukannya menjadi pembelajaran yang menarik, aktual, dan fungsional bagi siswa. Pemilihan metode pembelajaran oleh guru mempunyai dampak yang sangat esensial bagi perolehan belajar siswa. Kondisi pembelajaran IPS di Indonesia dewasa ini lebih diwarnai oleh pendekatan yang menekankan pada model belajar konvensional yang lebih banyak diwarnai dengan ceramah, sehingga kurang mampu merangsang siswa untuk terlibat secara aktif dalam proses belajarmengajar.

Kondisi pembelajaran seperti di atas jelas tidak mendorong pengembangan potensi diri siswa dalam pembelajaran, sehingga hasil belajar yang dicapai oleh siswa tidak optimal, karena guru hanya mencekoki pikiran siswa dengan konsepkonsep materi pelajaran yang bersifat hafalan saja. Pembelajaran seperti itu, nampaknya tidak mampu menunjang dan mendorong siswa untuk mengaktualisasikan potensi dirinya secara optimal. Suasana belajar yang demikian mendorong lahirnya pola interaksi yang searah yaitu hanya dari guru ke siswa saja, sehingga akan mematikan kreativitas dan menghambat pengembangan potensi diri siswa. Metode pembelajaran ceramah yang demikian, lebih cendrung berangkat dari asumsi dasar bahwa pembelajaran IPS hanya dimaksudkan untuk mentransfer pengetahuan atau konsep dari kepala guru ke kepala siswa. Akibatnya, mungkin guru telah merasa membelajarkan namun siswa belum belajar. Konsekuensi logis dari pola pembelajaran yang demikian pada dasarnya sudah merupakan pengingkaran terhadap tujuan dan peran kritis yang diemban oleh IPS. 
Berdasarkan indikator-indikator tersebut, nampaknya kualitas proses pembelajaran IPS dewasa ini masih sangat rendah. Kondisi pembelajaran IPS sebagaimana yang diuraikan di atas, menyebabkan siswa kurang bergairah dalam mempelajari IPS, karena siswa hanya akan berusaha menghafal materi yang diberikan oleh guru, tanpa berusaha mencari dan mengembangkan pengetahuan dan pemahamannya pada hal-hal lain yang baru untuk menunjang dan memantapkan pemahaman mereka mengenai materi IPS.

Berdasarkan analisis empirik terhadap kondisi pembelajaran IPS di sekolah dasar (SD) dan kajian terhadap tujuan, esensi, dan peran kritis yang diemban oleh IPS, nampaknya persoalan tersebut memerlukan suatu alternatif pemecahan yang sangat mendesak untuk menjembatani persoalan-persoalan seputar proses pembelajaran IPS khususnya pada jenjang SD. Artinya, diperlukan upaya-upaya yang terprogram untuk mengubah dan memperbaiki pola pembelajaran yang selama ini dikembangkan dan dilaksanakan oleh guru berdasarkan hasil kajian secara empiris dan pragmatis tentang realita yang terjadi di lapangan. Upaya tersebut dimaksudkan agar proses pembelajaran IPS yang dilakukan oleh guru dapat mencerminkan pola interaksi belajar yang kondusif dan mendukung pengalaman.

Salah satu alternatif yang diduga mampu menjembatani persoalan tersebut adalah dengan melakukan inovasi pada model pengorganisasian materi, metode pembelajaran, buku ajar, dan perangkat penilaian IPS, agar pembelajaran yang dilakukan dan dikembangkan oleh guru dapat memfasilitasi perkembangan potensi dan kreativitas siswa secara lebih optimal optimal. Guru sebagai subjek dalam pembelajaran memiliki peranan yang sangat penting dalam peningkatan kualitas pembelajaran harus mampu memilah metode belajar yang tepat agar partisipasi aktif siswa dalam pembelaajran dapat maksimal. Metode yang mampu mengaktifkan pembelajaran, meningkatkan pemahaman, kreativitas siswa dan imaginasi siswa sehingga pembelajaran lebih efektif adalah metode belajar Mind Mapping.

Mind Mapping merupakan peta rute yang terhebat bagi ingatan, memungkinkan kita menyusun fakta dan pikiran sedemikian rupa sehingga cara kerja alami otak dilibatkan sejak awal, ini berarti mengingat informasi akan lebih mudah dan lebih dapat diandalkan daripada menggunakan pencatatan tradisional (Buzan, 2007:4). Berdasarkan pemahaman tersebut Mind mapping merupakan metode pembelajaran yang mampu mengoptimalkan potensi siswa dalam belajar IPS. Metode Mind Mapping dipilih guru mata pelajaran IPS, karena beberapa hal, yakni: (1) mampu mempercepat siswa dalam memahami materi pelajaran IPS yang bersifat teoritis; (2) mampu menggambarkan kembali pemikiran siswa dalam suatu map (peta) yang dapat dimengerti siswa; (3) mampu mengaktifkan kerja otak kanan dan otak kiri melalui simbol, gambar, dan warna yang didrafkan dalam map; (4) dapat membantu siswa untuk berkonsentrasi (memusatkan perhatian) dan lebih baik dalam menginggat; (5) dapat membantu siswa meningkatkan kecerdasan visual dan kecerdasan observasi; dan (6) dapat menimbulkan kreativitas dan imajinasi siswa dalam mengkaji pelajaran IPS secara efektif.

Pembelajaran IPS dengan menggunakan metode Mind Mapping mengharuskan siswa untuk membuat karya map masing-masing sesuai dengan 
pokok bahasan yang dikaji, hal ini dikarenakan pemikiran, pemahaman dan imaginasi siswa berbeda-beda satu sama lain. Dengan membuat Mind Map sendiri pada saat pelajaran, siswa akan lebih cepat dalam menangkap materi yang diajarkan guru, waktu pembelajaran menjadi lebih efektif, dan siswa lebih cepat dalam memahami materi. Melalui Mind Mapping diharapkan mampu mendongkrak hasil belajar siswa pada mata pelajaran IPS.

\section{B. PEMBAHASAN}

\section{Konsep Ilmu Pengetahuan Sosial}

Menurut Solihatin (2008:14-15) IPS adalah suatu ilmu yang membahas hubungan antara manusia dan lingkungannya. Lingkungan masyarakat dimana anak didik tumbuh dan berkembang sebagai bagian dari masyarakat, dihadapkan dalam berbagai permasalahan yang terjadi di lingkungan sekitarnya. Pendidikan IPS berusaha membantu siswa dalam memecahkan permasalahan yang dihadapi sehingga menjadikan siswa semakin mengerti dan memahami lingkungan sosial masyarakatnya. Menurut NCSS (National Courcil for Social studies) definisi IPS, yakni the study of political, economic, cultural, and environmental aspects of societies in the past, present, and future (Saidiharjo, 2004:31).

IPS adalah pengetahuan tentang politik, ekonomi, budaya dan aspek lingkungan social pada masa lampau, sekarang dan akan datang. IPS merupakan salah satu mata pelajaran yang menggunakan pendekatan integrasi dibeberapa mata pelajaran (geografi, ekonomi, dan sejarah) untuk kepentingan pembelajaran di sekolah. IPS dirumuskan atas dasar realitas dan fenomena sosial yang mewujudkan suatu pendekatan interdisipliner dari aspek dan cabang-cabang ilmuilmu social (sosiologi, geografi, ekonomi, politik, hukum, dan budaya) terlihat dalam Gambar 1. Tujuan pendidikan IPS pada dasarnya dapat dikelompokkan menjadi empat kategori, yaitu:

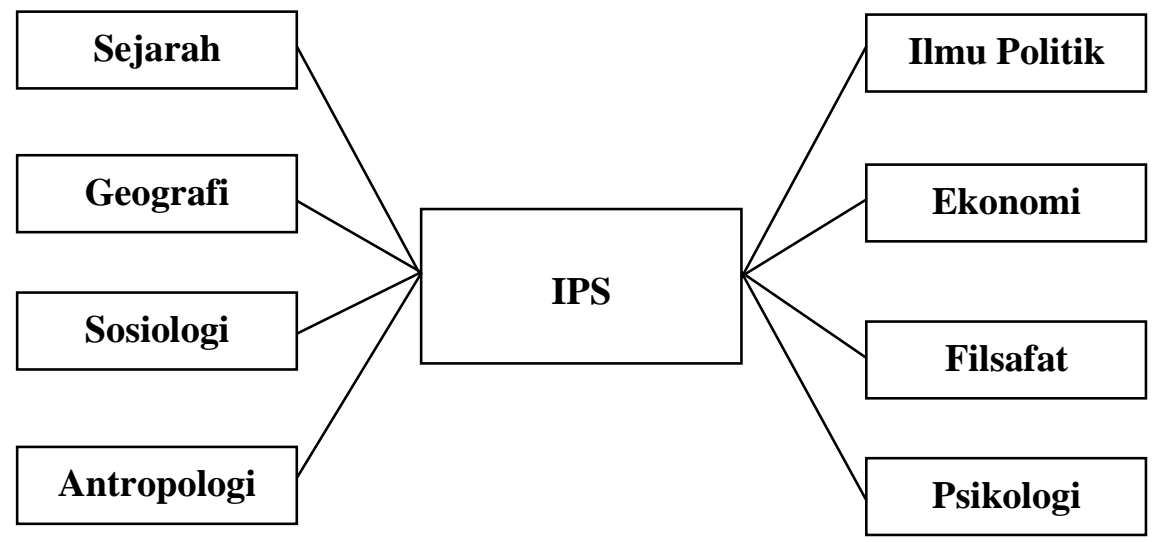

\section{Gambar 1 Bentuk Pelajaran Ilmu Pengetahuan Sosial}

a. Knowledge, merupakan tujuan utama pendidikan IPS, yaitu membantu para siswa belajar tentang diri mereka sendiri dan lingkungannya. Hal -hal yangdipelajari sehubungan dengan ini adalah geografi, sejarah, politik, ekonomi, antropologi dan sosiopsikologi; 
b. Skill (ketrampilan), berhubungan dengan tujuan pendidikan IPS, mencakup ketrampilan berpikir (thinking skills);

c. Attitude (sikap), dikelompokkan menjadi dua, yaitu kelompok sikap yang diperlukan untuk tingkah laku berpikir dan tingkah laku sosial;

d. Value, dalam hubungan ini adalah nilai yang terkandung dalam masyarkat yang di dapatkan dari lingkungan masyarakat sekitar maupun lembaga pemerintahan, termasuk di dalamnya adalah nilai-nilai kepercayaan, nilai ekonomi, pergaulan antar manusia, ketaatan pada pemerintah, dan hukum.

Pembelajaran IPS berusaha membantu siswa dalam memecahkan permasalahan-permasalahan yang dihadapi, sehingga akan menjadikannya semakin mengerti dan memahami lingkungan sosial masyarakatnya (Cleaf, 1991). IPS dibelajarkan di SD, dimaksudkan agar siswa menjadi manusia dan warga negara yang baik, seperti yang diharapkan oleh dirinya, orangtua, masyarakat, dan agama (Somantri, 2004). Tujuan institusional penyelenggaraan pendidikan di SD adalah: (1) mendidik siswa agar menjadi manusia Indonesia seutuhnya berdasarkan Pancasila yang mampu membangun dirinya sendiri serta ikut bertanggung jawab terhadap pembangunan bangsa; (2) memberi bekal kemampuan yang diperlukan bagi siswa untuk melanjutkan pendidikan ke tingkat yang lebih tinggi; dan (3) memberi bekal kemampuan dasar untuk hidup di masyarakat dan mengembangkan diri sesuai dengan bakat, minat, kemampuan dan lingkungannya (Depdiknas, 2006).

Berdasarkan pada beberapa pandangan di atas, dapat diformulasikan bahwa pada dasarnya tujuan dari pembelajaran IPS pada jenjang SD adalah untuk mendidik dan memberi bekal kemampuan dasar kepada siswa untuk mengembangkan diri sesuai dengan bakat, minat, kemampuan dan lingkungannya, serta sebagai bekal bagi siswa untuk melanjutkan pendidikan ke jenjang yang lebih tinggi.

\section{Metode Pembelajaran Mind Mapping}

Metode pembelajaran ini pertama kali dikenalkan oleh Tony Buzan. Buzan mengemukakan: A Mind Map is a powerful graphic technique wich rovider a universal key to unlock the potential of the brain. It harnesses the full range of cortical skill-word, image, number, logic, rhythm, colour and spatial awarenessin a single, uniquety powerful manner. In so doing, it gives you the freedomto room the infinite expanse of your brain. Inti dari Mind Map ini teknik membuat catatan menggunakan kata kunci yang dipahami siswa menggunakan seluruh hasil dari konsep-konsep kortikal yaitu kata-kata, imajinasi, nomer, logika, irama, warna dan ruang pengetahuan dalam satu cara yang unik, dengan harapan siswa mampu menangkap dan memahami materi pelajaran secara efektif.

Hal senanda diungkapkan oleh Pressley \& Vanmetter bahwa Mind Map (peta pikiran) merupakan cara grafis untuk mewakili ide-ide dan konsep, pemikiran visual struktur alat yang membantu informasi, membantu siswa untuk lebih mudah dalam: menganalisis, memahami, mensitesis, mengingat, dan menghasilkan ide-ide baru. Mind map dapat membantu guru dalam pembelajaran agar efektif. Manfaat mind map, yakni: (1) membantu guru dalam merencanakan 
pembelajaran, menciptakan komunikasi efektif, memacu kreativitas; (2) menghemat waktu pembelajaran; (3) siswa dapat lebih cepat memusatkan perhatian terhadap materi yang dikaji, siswa dapat menyusun dan menjelaskan pikiran-pikiran yang telah di-map-kan secara detail; dan (4) meningkatkan kemampuan mengingat siswa dan menjadikan siswa belajar lebih cepat dan efisien dengan melihat "gambaran keseluruhan" dari map materi yang telah dibuat oleh siswa.

Manfaat dari Mind Mapping menurut Olivia (2008:8) adalah: (1) membantu untuk berkonsentrasi (memusatkan perhatian) dan lebih baik dalam menginggat; (2) meningkatkan kecerdasan visual dan kecerdasan observasi; (3) melatih kemampuan berpikir kritis dan komunikatif; (4) melatih inisiatif dan rasa ingin tahu; (5) meningkatkan kreativitas dan daya cipta; (6) membuat catatan dan ringkasan pelajaran yang lebih baik; (7) membantu mendapatkan dan memunculkan ide atau cerita yang brilian; (8) meningkatkan kecerdasan berpikir dan mandiri; (9) menghemat waktu; (10) membantu mengembangkan diri serta merangsang pengungkapan pemikiran; (11) membantu menghadapi ujian dengan mudah dan mendapat nilai yang lebih bagus; (12) membantu mengatur pikiran, hobi, dan hidup kita; (13) melatih koordinasi gerakan dan tangan dan mata; (14) mendapatkan kesempatan lebih banyak untuk bersenang-senang; (15) membuat tetap fokus pada ide utama maupun semua ide tambahan; dan (16) membantu menggunakan kedua belah otak yang membuat siswa ingin terus menerus belajar.

Penggunaan Mind Mapping dapat membantu kita dalam merencanakan dan mengatur hidup demi keberhasilan maksimal, memunculkan ide-ide baru yang kreatif dan mengagumkan, dan menyerap fakta serta informasi dengan sangat mudah. Melalui Mind Mapping kita juga akan mengenal otak dengan lebih baik dan menemukan cara memudahkan otak belajar dan mengingat informasi.

\section{Belajar Berbasis Peta Pikiran (Mind Mapping)}

Belajar didefinisikan sebagai semua perubahan pada kapabilitas dan perilaku organisme, baik secara mental maupun fisik, yang diakibatkan oleh pengalaman baik langsung maupun tidak langsung. Berdasarkan tinjauan psikologis, belajar merupakan aktivitas pemrosesan informasi dan pembentukan pengetahuan (proses kognitif). Menurut Peaget setiap anak memiliki skema (scheme) yang merupakan konsep atau kerangka yang eksis di dalam pikiran individu yang dipakai untuk mengorganisasikan dan menginterpretasikan informasi. Sedangkan menurut Vygotsky kemampuan kognitif dimediasi dengan kata, bahasa, dan bentuk diskursus, yang berfungsi sebagai alat psikologis untuk membantu dan mentransformasi aktivitas mental.

Fakta yang harus disadari, bahwa dunia pembelajaran bagi anak saat ini dibanjiri dengan informasi yang up to date setiap saat. Ketidakmampuan memproses informasi secara optimal di tengah arus informasi menyebabkan banyak individu yang mengalami hambatan dalam belajar ataupun bekerja. Hambatan pemrosesan informasi terletak pada dua hal utama, yaitu proses pencatatan dan proses penyajian kembali. Keduanya merupakan proses yang saling berhubungan satu sama lain. 
Seringkali individu dalam hal pencatatan tanpa disadari membuat catatan yang tidak efektif. Sebagian besar melakukan pencatatan secara linear, bahkan tidak sedikit pula yang membuat catatan dengan menyalin langsung seluruh informasi yang tersaji pada buku atau penjelasan lisan tanpa menyaring atau menyeleksi terlebih dahulu informasi yang didapatkan. Hal ini mengakibatkan hubungan antar ide atau informasi menjadi sangat terbatas dan spesifik, sehingga berujung pada minimnya kreativitas yang dapat dikembangkan setelahnya.

Selain itu, bentuk pencatatan seperti ini juga memunculkan kesulitan untuk mengingat dan menggunakan seluruh informasi tersebut dalam belajar. Sedangkan dalam hal penyajian kembali informasi, kemampuan yang paling dibutuhkan adalah memanggil ulang (recalling) informasi yang telah dipelajari. Pemaggilan ulang merupakan kemampuan menyajikan secara tertulis atau lisan berbagai informasi dan hubungannya, dalam format yang sangat personal. Hal ini merupakan salah satu indikator pemahaman individu atas informasi yang diberikan. Sehingga dengan demikian, proses pemanggilan ulang sangat erat hubungannya dengan proses pengingatan atau remembering.

Bentuk pencatatan yang dapat mengakomodir adalah dengan peta pikiran (Mind Map). Individu dengan peta pikiran, dapat mengantisipasi derasnya laju informasi dengan memiliki kemampuan mencatat yang memungkinkan terciptanya "hasil cetak mental" (mental computer printout). Hal ini tidak hanya dapat membantu dalam mempelajari informasi yang diberikan, namun dapat merefleksikan pemahaman personal yang mendalam atas informasi tersebut. Selain itu Mind Mapping juga memungkinkan terjadinya asosiasi yang lebih lengkap pada informasi yang ingin dipelajari, baik asosiasi antarsesama informasi yang ingin dipelajari ataupun dengan informasi yang telah tersimpam sebelumnya diingatan.

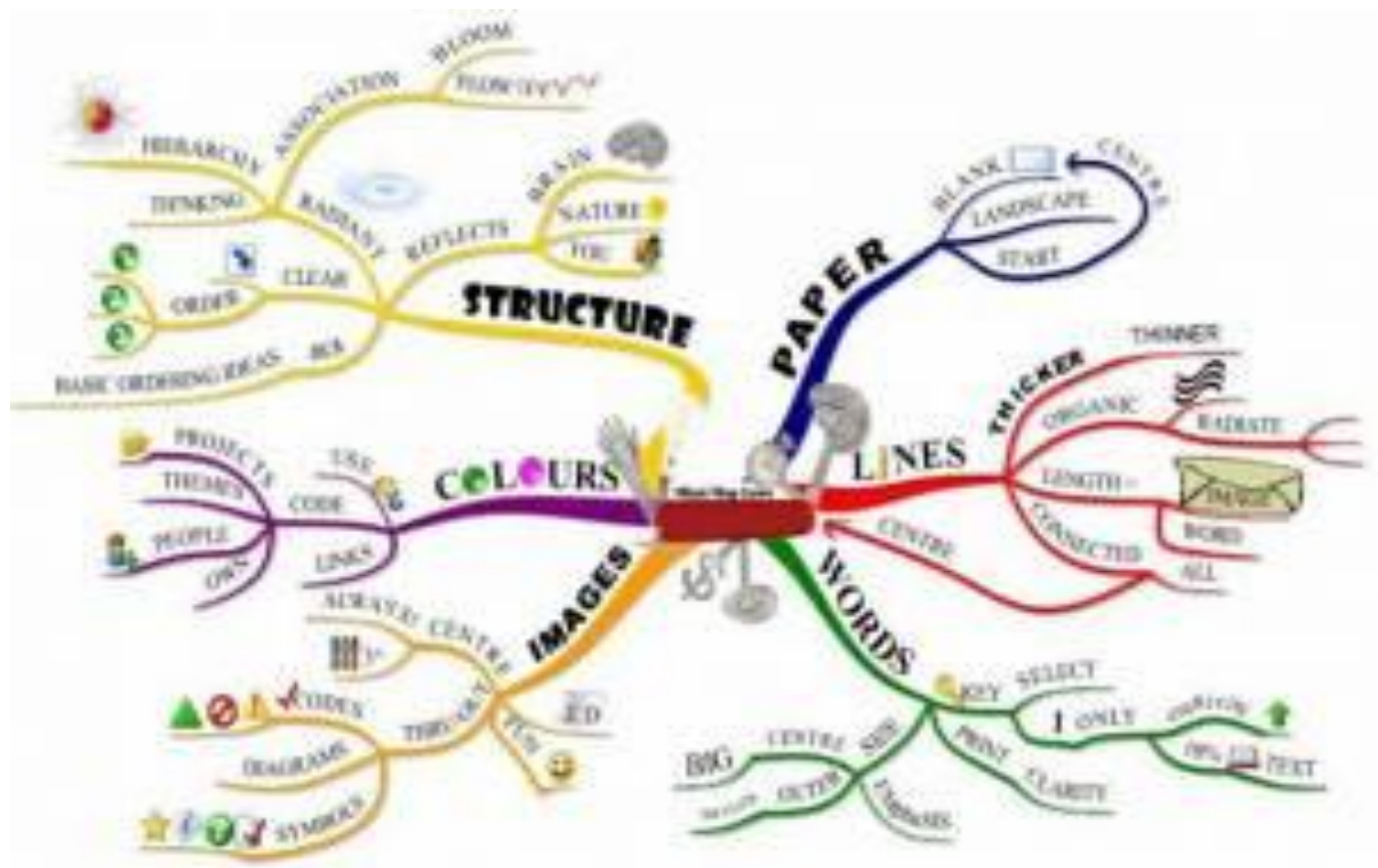

Gambar 2 Display Mind Mapping 
Buzan mengemukakan bahwa Mind Mapping (peta pikiran) merupakan suatu teknik grafik yang sangat ampuh dan menjadi kunci yang universal untuk membuka potensi dari seluruh otak, karena menggunakan seluruh keterampilan yang terdapat pada bagian neokorteks dari otak atau yang lebih dikenal sebagai otak kiri dan otak kanan. Mind Mapping (peta pikiran) mampu menyeimbangkan kinerja otak, karena dalam Mind Map terdapat kata kunci, simbol, gambar, warna dan garis-garis yang mampu mengoptimalkan kerja otak. Struktur Mind Map terlihat dalam Gambar 2.

Ditinjau dari segi waktu Mind Mapping juga dapat mengefisienkan penggunaan waktu dalam mempelajari suatu informasi. Hal ini utamanya disebabkan karena Mind Mapping dapat menyajikan gambaran menyeluruh atas suatu hal, dalam waktu yang lebih singkat. Dengan kata lain, Mind Mapping mampu memangkas waktu belajar dengan mengubah pola pencatatan linear yang memakan waktu menjadi pencatatan yang efektif yang sekaligus langsung dapat dipahami oleh individu. Mind Mapping bertujuan membuat materi pelajaran terpola secara visual dan grafis yang akhirnya dapat membantu merekam, memperkuat, dan mengingat kembali informasi yang telah dipelajari. Tabel 1 menyajikan perbedaan antara catatan tradisional (catatan biasa) dan catatan pemetaan pikiran (Mind Mapping).

Tabel 1 Perbedaan Catatan Biasa dan Mind Mapping

\begin{tabular}{ll}
\multicolumn{1}{c}{ Catatan Biasa } & \multicolumn{1}{c}{ Mind Mapping } \\
\hline Hanya berupa tulisan-tulisan saja & Berupa tulisan, symbol dan gambar \\
\hline Hanya dalam satu warna & Berwarna-warni \\
\hline Untuk mereview ulang memerlukan waktu & $\begin{array}{l}\text { Untuk mereview ulang diperlukan waktu } \\
\text { yang lama }\end{array}$ \\
\hline $\begin{array}{l}\text { Waktu yang diperlukan untuk belajar lebih } \\
\text { lama }\end{array}$ & $\begin{array}{l}\text { Waktu yang diperlukan untuk belajar } \\
\text { lebih cepat dan efektif }\end{array}$ \\
\hline Statis & Membuat individu menjadi lebih kreatif. \\
\hline
\end{tabular}

Berdasarkan kajian tersebut Mind Mapping adalah satu teknik mencatat yang mengembangkan gaya belajar visual. Mind Mapping memadukan dan mengembangkan potensi kerja otak yang terdapat di dalam diri seseorang. Dengan adanya keterlibatan kedua belahan otak maka akan memudahkan seseorang untuk mengatur dan mengingat segala bentuk informasi, baik secara tertulis maupun secara verbal. Adanya kombinasi warna, simbol, bentuk dan sebagainya memudahkan otak dalam menyerap informasi yang diterima. Mind Mapping yang dibuat oleh siswa dapat bervariasi pada setiap materi. Hal ini disebabkan karena berbedanya emosi dan perasaan yang terdapat dalam diri siswa setiap saat.

Suasana menyenangkan yang diperoleh siswa ketika berada di ruang kelas pada saat proses belajar akan mempengaruhi penciptaan peta pikiran. Dengan demikian, guru diharapkan dapat menciptakan suasana yang dapat mendukung kondisi belajar siswa terutama dalam proses pembuatan Mind Mapping. Proses belajar yang dialami seseorang sangat bergantung kepada lingkungan tempat belajar. Jika lingkungan belajar dapat memberikan sugesti positif, maka akan baik 
dampaknya bagi proses dan hasil belajar, sebaliknya jika lingkungan tersebut memberikan sugesti negatif maka akan buruk dampaknya bagi proses dan hasil belajar. Guru dalam penerapan Mind Mapping di sekolah, bertindak sebagai fasilitator memberikan pengarahan kepada siswa mengenai metode mind mapping terlebih dahulu kepada siswa, setelah siswa memahami konsep mengenai mind map siswa membaca materi yang akan dikaji, dan guru memberikan contoh cara mengaplikasikan materi dalam sebuah mind map (peta pikiran), kemudian siswa mengimplementasi mind mapping sesuai materi yang dikaji. Langkah-langkah dalam pembuataan mind mapping, yakni:

a. Langkah awal adalah menyiapkan bahan-bahan untuk membuat Mind Mapping yaitu kertas kosong tak bergaris, pena atau pensil warna dan stabilo yang didukung oleh otak dan imajinasi;

b. Mulailah dari bagian tengah kertas kosong yang sisi panjangnya diletakkan mendatar. Hal ini dikarenakan mulai dari tengah memberi kebebasan pada otak untuk menyebar ke segala arah dan untuk mengungkapkan dirinya dengan lebih bebas dan alami;

c. Gunakan gambar atau foto untuk ide sentral anda, karena sebuah gambar bermakna seribu kata dan membantu kita menggunakan imajinasi. Sebuah gambar sentral akan lebih menarik, membantu kita tetap terfokus, membantu kita berkonsentrasi dan mengaktifkan otak;

d. Gunakan warna, karena bagi otak, warna sama menariknya dengan gambar. Warna membuat Mind Mapping lebih hidup, menambah energi kepada pemikir kreatif dan menyenangkan;

e. Hubungkan cabang-cabang utama ke gambar pusat dan hubungkan cabangcabang tingkat dua dan tingkat tiga ke tingkat satu dan dua, dan seterusnya. Hal ini dikarenakan otak bekerja menurut asosiasi. Otak senang mengaitkan dua (atau tiga atau empat) hal sekaligus. Bila kita menghubungkan cabangcabang, kita akan mudah mengingat;

f. Buatlah garis hubung yang melengkung, bukan garis lurus, karena garis lurus akan membosankan otak. Cabang-cabang yang melengkung dan organis, seperti cabang-cabang pohon jauh lebih menarik bagi mata;

g. Gunakan satu kata kunci untuk setiap garis, karena kata kunci tunggal dapat memberi lebih banyak daya dan fleksibelitas kepada Mind Mapping.

\section{Hubungan Pembelajaran Berbasis Peta Pikiran (Mind Mapping) dengan Hasil Belajar dan Kreativitas Siswa}

Prestasi belajar adalah puncak hasil belajar yang dapat mencerminkan keberhasilan belajar siswa terhadap pencapaian tujuan belajar yang telah ditetapkan. Hasil belajar siswa dapat meliputi aspek kognitif (pengetahuan), afektif (sikap), dan psikomotorik (tingkah laku). Salah satu tes yang dapat melihat pencapaian hasil belajar siswa adalah dengan melakukan tes prestasi belajar. Tes prestasi belajar yang dilaksanakan oleh siswa memiliki peranan penting, baik bagi guru ataupun bagi siswa yang bersangkutan. Bagi guru, tes prestasi belajar dapat mencerminkan sejauh mana materi pelajaran dalam proses belajar dapat diikuti dan diserap oleh siswa sebagai tujuan instruksional. Bagi siswa tes prestasi belajar 
bermanfaat untuk mengetahui sebagai mana kelemahan-kelemahannya dalam mengikuti pelajaran.

Mind Mapping atau pemetaan pikiran merupakan salah satu teknik mencatat tingkat tinggi. Informasi berupa materi pelajaran yang diterima siswa dapat diingat dengan bantuan catatan. Peta pikiran merupakan bentuk catatan yang tidak monoton karena memadukan fungsi kerja otak secara bersamaan dan saling berkaitan satu sama lain. Dengan demikian akan terjadi keseimbangan kerja kedua belahan otak. Otak dapat menerima informasi berupa gambar, simbol, citra, dan musik yang berhubungan dengan fungsi kerja otak kanan.

Pembelajaran konvensional adalah pembelajaran yang memusatkan kegiatan belajar pada guru. Siswa hanya duduk, mendengarkan dan menerima informasi. Cara penerimaan informasi akan kurang efektif karena tidak adanya proses penguatan daya ingat, walaupun ada proses penguatan yang berupa pembuatan catatan, siswa membuat catatan dalam bentuk catatan yang monoton dan linear.

Penggunaan metode pembelajaran yang sesuai sangat menentukan keberhasilan belajar siswa. Dengan metode pembelajaran yang sesuai, siswa dapat mencapai prestasi belajar yang tinggi dan dapat mengembangkan potensi yang tersimpan dalam dirinya. Proses belajar siswa sangat dipengaruhi oleh emosi di dalam dirinya. Emosi dapat mempengaruhi pencapaian hasil belajar apakah hasilnya baik atau buruk. Pembelajaran berbasis peta pikiran, berusaha menggabungkan kedua belahan otak yakni otak kiri yang berhubungan dengan hal yang bersifat logis (seperti belajar) dan otak kanan yang berhubungan dengan keterampilan (aktivitas kreatif). Dengan demikian, adanya teknik Mind Mapping atau pemetaan pikiran diharapkan dapat meningkatkan pencapaian hasil belajar siswa.

\section{KESIMPULAN}

IPS merupakan mata pelajaran yang memerlukan metode mengajar yang tepat. Hal ini dikarenakan IPS merupakan mata pelajaran yang bersifat teortis dimana banyak materi yang perlu dihafal dan diingat oleh siswa. Siswa memerlukan teknik pencatatan yang lebih variatif lagi yang mampu mengaktifkan kerja otak kanan dan kiri, sehingga siswa mampu menginggat materi dalam jangka waktu lama dan lebih menghemat waktu belajar. Oleh karena itulah siswa memerlukan metode Mind Mapping.

Mind Mapping merupakan teknik pencatatan efektif yang mampu mengembangkan daya pikir, imaginasi, kreativitas, dan pengoptimalan otak siswa. Mind Mapping sangat baik diterapkan dalam pembelajaran dalam rangka meningkatkan hasil belajar siswa dalam pembelajaran. Guru memiliki peranan yang sangat penting dalam pembelajaran, pembelajaran yang efektif apabila siswa terlibat langsung dalam pemebalajran dan memiliki pengalaman langsung terhadap pelajaran yang diajarkan oleh guru. Guru dengan Mind Mapping dapat memaksimalkan potensi siswa dalam pemebalajran, dengan siswa membuat sendiri map-nya sesuai dengan daya pikir, kreativitas, dan logika siswa.

Melalui map-nya itu pula siswa dapat lebih memahami materi yang dikaji dikarenakan siswa membuat sendiri karya map tersebut, siswa lebih cepat 
menangkap materi yang diajarkan guru, siswa lebih tertarik belajar IPS dikarenakan Mind Mapping menggunakan warna, simbol, dan gambar yang disesuaikan materi, serta pemikiran siswa menjadi lebih tersistematis. Berdasarkan hal tersebut Mind Mapping diasumsikan mampu meningkatkan hasil belajar siswa terutama pada mata pelajaran IPS. 


\section{DAFTAR RUJUKAN}

Buzan, T. 2006(a). Mind Mapping, (Online). (http://en.wikipedia.org /wiki/mindmap\#orgin.html, diakses 6 November 2012).

Buzan, T. 2006(b). What is a Mind Mapping, (Online). (http://member.optusnet.com/charles70/creative/mindmap/mindmapfaq.html \#whatismindmap, diakses 6 November 2012).

Buzan, T. 2006(c). Benefit of Mind Mapping, (Online). (http://www.tonybuzan.com.au/learning/benefitofmindmapping.html, diakses 6 November 2012).

Buzan, T. 2007. Buku Pintar Mind Map. Jakarta: PT. Gramedia Pustaka.

Hall, G. E., dan Quinn, L. F. 2008. Mengajar dengan Senang Menciptakan Perbedaan dalam Pembelajaran Siswa. Terjemahan oleh Soraya Ramli. Jakarta: PT. Indeks.

Hidayati. 2002. Bahan Ajar Pendidikan IPS di Sekolah Dasar. Yogyakarta: FIP UNY.

Kartikasari, M. 2012. Diktat Kuliah Pengenalan dan Pembelajaran IPS SD Sebuah Konsep Dasar IPS SD. Madiun: IKIP PGRI Madiun.

Nurcahyo, A., dan Hartono, Y. 2010. Konsep Dasar dan Pengembangan IPS-SD. Magetan: LS_Swastika Press.

Olivia, F. 2008. Gembira dengan Mind Mapping Bantu Anak Menguasai Senjata Rahasia Para Jenius untuk Melejitkan Prestasi di Sekolah. Jakarta: Gramedia.

Pressley, M., dan Vanmetter. 2006. Mind Mapping and How to Get Immediately, (Online). (http://journal_litemind.com/what-is-the-mind-mapping/html, diakses 16 Januari 2010).

Saidiharjo. 1996. Konsep Dasar IPS. Yogyakarta: FIP IKIP Yogyakarta.

Saidiharjo. 2002. Pengembangan Materi IPS Terpadu. Yogyakarta: Program Pascasarjana Universitas Negeri Yogyakarta.

Saidiharjo. 2004. Pengembangan Kurikulum IPS. Yogyakarta: Pascasarjana Universitas Negeri Yogyakarta. 
Sharon, M. S., dan Susan, M. A. 2003. Teaching and Learning At a Distance: Foundations of Distance Education. United State of Amerika: Pearson Education.

Subroto, W., T. 2007. Pendidikan IPS. Surabaya: Insan Cendikia.

Tim PLPG. 2008. Strategi dan Metode Pembelajaran IPS. Makasar: Universitas Negeri Makasar. 